\title{
The effect of varying the sodium or potassium intake, or both, on magnesium status in the rat
}

\author{
BY JUDITH A. CHARLTON*ANDD. G. ARMSTRONG \\ Department of Agricultural Biochemistry and Nutrition, Faculty of Agriculture, University of \\ Newcastle upon Tyne, Newcastle upon Tyne NE1 $7 R U$
}

(Received 26 September 1988 - Accepted 26 April 1989)

\begin{abstract}
Alterations in sodium or potassium intake, or both, affect the distribution and excretion of magnesium in man and animals. Experiments were performed on rats to investigate the effect of varying $\mathrm{Na}, \mathrm{K}$ or $\mathrm{Na}+\mathrm{K}$ intakes on $\mathrm{Na}, \mathrm{K}$ and $\mathrm{Mg}$ excretion and plasma and tissue concentrations. In Expt 1, increasing the $\mathrm{Na}$ intake in a linear fashion produced a significant $(P<0.05)$ quadratic response in urinary $\mathrm{Mg}$ excretion, with a decrease followed by an increase as $\mathrm{Na}$ intake rose. No effect was observed on faecal excretion of Mg. Plasma and tissues were sampled at the end of an $18 \mathrm{~d}$ collection period; concentrations of aldosterone in plasma and $\mathrm{Mg}, \mathrm{Na}$ and $\mathrm{K}$ in plasma and tissue were determined. Increasing $\mathrm{Na}$ intake in a linear fashion produced a significant $(P<0.05)$ quadratic effect on $\mathrm{Mg}$ concentration in heart and muscle, i.e. a decrease followed by an increase as $\mathrm{Na}$ intake rose; $\mathrm{Na}$ intake did not affect liver or bone $\mathrm{Mg}$ concentrations. There were no significant effects of $\mathrm{Na}$ intake on plasma $\mathrm{Mg}, \mathrm{Na}$ or aldosterone but plasma $\mathrm{K}$ fell significantly $(P<\mathbf{0 . 0 1})$ as $\mathrm{Na}$ intake increased. In Expt 2, constant amounts of four diets supplying adequate or high levels of $\mathrm{Na}$ and adequate or high levels of $\mathrm{K}$ but a constant intake of $\mathrm{Mg}$ were given to rats. The rats fed on the adequate-Na diet had a significantly $(P<0.05)$ higher urinary $\mathrm{Mg}$ excretion than those fed on the high- $\mathrm{Na}$ diet; $\mathrm{Na}$ intake did not affect faecal $\mathrm{Mg}$ excretion.
\end{abstract}

Magnesium status: Potassium intake: Sodium intake: Rat

Sodium is the most abundant extracellular cation in the mammalian body whilst potassium and magnesium predominate intracellularly. As a result of the functional relation amongst these elements in maintaining osmolality and acid-base balance, nutritional interactions amongst these elements may be anticipated. Nutritional manipulation of dietary $\mathrm{Na}, \mathrm{K}$ and $\mathrm{Mg}$ has resulted in altered mineral excretion and tissue composition leading to impaired growth in man and animals (Forbes, 1966; Duarte, 1980; Ryan \& Whang, 1983).

The interrelationships between these cations are complex, with reduced $\mathrm{Na}$ intake or elevated $\mathrm{K}$ intake, or both, decreasing apparent absorption of $\mathrm{Mg}$ in the ruminant leading to hypomagnesaemia (Morris \& Gartner, 1975) whilst in other species $\mathrm{Mg}$ deficiency induces increased $\mathrm{Na}$ and decreased $\mathrm{K}$ concentrations in muscle and heart (Ebel \& Günther, 1980).

In addition, the mineralocorticoid aldosterone which is stimulated by low $\mathrm{Na}$ or high $\mathrm{K}$ intakes, or both, has been demonstrated to increase $\mathrm{Mg}$ excretion in the urine of rats (Hanna \& MacIntyre, 1960) and sheep (Scott \& Dobson, 1965) and to affect the distribution of $\mathrm{Mg}$ in the tissues (Duarte, 1980).

Even though research continues to provide information on the interactions between $\mathrm{Na}$, $\mathrm{K}$ and $\mathrm{Mg}$, little effort has been directed toward determining the effect of these elements on the absorption, excretion and tissue distribution of one another. Therefore, the aim of the present study was to evaluate the effect of different dietary concentrations of $\mathrm{Na}$ and $\mathrm{K}$ on the apparent absorption, excretion, plasma concentration and distribution of $\mathrm{Na}, \mathrm{K}$ and

* Present address: Department of Medicine, New Medical School, Framlington Place, Newcastle upon Tyne NE2 $4 \mathrm{HH}$. 
$\mathrm{Mg}$ in the rat. Plasma aldosterone concentrations were also estimated because of their possible involvement in the physiology of $\mathrm{Na}, \mathrm{K}$ and $\mathrm{Mg}$.

\section{MATERIALS AND METHODS}

\section{Animals and diets}

Expt 1. Twenty-five male Albino Wistar rats, mean age 6 weeks and mean weight $100 \mathrm{~g}$, were randomly divided into five equal groups and allocated to individual metabolism cages which allowed for the separate collection of faeces and urine. Each animal was given 15 $\mathrm{g}$ fresh weight/d of a starch-based diet containing varying amounts of $\mathrm{Na}(\mathrm{mg} / \mathrm{d})$ : group 1,16 ; group 2, 20.5; group 3, 25; group 4, 34; group 5, 43. $\mathrm{Mg}$ intake was maintained at $4.1 \mathrm{mg} / \mathrm{d}$ and $\mathrm{K}$ intake at $34 \mathrm{mg} / \mathrm{d}$ for all rats. The dietary constituents were $(\mathrm{g} / \mathrm{kg}): 520$ starch, 160 glucose, 100 maize oil, 100 albumin, 80 cellulose, 40 minerals and vitamins. For details of the mineral content of the diet, see Table 1. All rats were allowed continuous access to distilled water.

Expt 2. Four groups each of five rats were given individually one of four diets containing varying amounts of $\mathrm{Na}$ and $\mathrm{K}$, but a constant amount of $\mathrm{Mg}(7.3 \mathrm{mg} / \mathrm{d})$ for each rat. Individual $\mathrm{Na}$ and $\mathrm{K}$ intakes were as follows: diet 1 received adequate $\mathrm{Na}$ and $\mathrm{K}$ (16 and $88 \mathrm{mg} / \mathrm{d}$ respectively), diet 2 high $\mathrm{Na}$ and adequate $\mathrm{K}(23.5$ and $88 \mathrm{mg} / \mathrm{d}$ respectively), diet 3 adequate $\mathrm{Na}$ and high $\mathrm{K}$ (16 and $142 \mathrm{mg} / \mathrm{d}$ respectively), diet 4 high $\mathrm{Na}$ and high $\mathrm{K}$ (23.5 and $142 \mathrm{mg} / \mathrm{d}$ respectively). 'Adequate' and 'high' relate to the values recommended by the (US) National Research Council (1978). The remaining dietary constituents were as used in Expt 1. For details of the mineral content of the diet, see Table 1.

\section{Collection of samples for analysis}

After adaptation to the diets, total faeces and urine were collected every $2 \mathrm{~d}$ for an $18 \mathrm{~d}$ period. Urine was stored frozen at $-18^{\circ}$ and faeces dried at $104^{\circ}$ to constant weight and stored dried. The animals were then killed by diethyl ether inhalation and bled by open cardiac puncture. Blood was immediately centrifuged at $4^{\circ}$ and plasma separated by aspiration and stored at $-18^{\circ}$. The heart, liver, quadriceps femoris and femur were removed, dissected free of fat and dried at $104^{\circ}$ to constant weight before analysis.

\section{Analyses}

Weighed and dried samples of diet, faeces and tissue were wet-ashed in a nitricsulphuric-perchloric acid mixture (Kirkbright \& Sargent, 1974). Urine and plasma were diluted with distilled water before analysis. $\mathrm{Na}$ and $\mathrm{K}$ were determined by flame photometry (Corning 400; Corning, Halstead, Essex). Mg was determined by atomic absorption spectrophotometry (Pye Unicam SP9, Pye Unicam, Cambridge). Plasma aldosterone was determined by radioimmunoassay by the method described by DeMan et al. (1980).

\section{Statistical analysis}

The faecal, urine, balance, plasma and tissue values were examined by one-way analysis of variance. Faecal and urinary values for individual collection periods were summed before statistical analysis. In Expt 1 the effects of $\mathrm{Na}$ content of the diet were tested against the between-animals, within-diets variation using orthogonal polynominals to test the shapes of responses, linear or quadratic (Dixon, 1983). The linear and quadratic coefficients were derived by J. C. Mathers (personal communications) and are shown in Table 2. In Expt 2 the effects of $\mathrm{Na}$ intake, $\mathrm{K}$ intake and the interaction between $\mathrm{Na}$ and $\mathrm{K}$ intakes were tested against the between-animals, within-diets variation. 
Table 1. Expts 1 and 2. The composition of the mineral supplement ( $\mathrm{g} / \mathrm{kg}$ supplement) fed to rats

\begin{tabular}{lcc}
\hline & Expt I & Expt 2 \\
\hline $\mathrm{NaCl}$ & $0,19 \cdot 1,38 \cdot 2,76 \cdot 3,114 \cdot 4$ & $0,31 \cdot 8$ \\
$\mathrm{KH}_{2} \mathrm{PO}_{4}$ & $162 \cdot 5$ & 477,953 \\
$\mathrm{MgCl}_{2} \cdot 6 \mathrm{H}_{2} \mathrm{O}$ & $46 \cdot 3$ & $92 \cdot 6$ \\
$\mathrm{CaCO}_{3}$ & 625 & 625 \\
$\mathrm{MnSO}_{4} \cdot 4 \mathrm{H}_{2} \mathrm{O}$ & $10 \cdot 2$ & $10 \cdot 2$ \\
$\mathrm{FeSO}_{4} \cdot 7 \mathrm{H}_{2} \mathrm{O}$ & $8 \cdot 7$ & $8 \cdot 7$ \\
$\mathrm{ZnSO}_{4} \cdot 7 \mathrm{H}_{2} \mathrm{O}$ & $2 \cdot 7$ & $2 \cdot 7$ \\
$\mathrm{CuSO}_{4} \cdot 5 \mathrm{H}_{2} \mathrm{O}$ & $1 \cdot 0$ & $1 \cdot 0$ \\
$\mathrm{KIO}_{3}$ & $0 \cdot 1$ & $0 \cdot 1$ \\
\hline
\end{tabular}

Table 2. Expt 1. Dietary intake and mean output of magnesium, sodium and potassium in faeces and urine ( $\mathrm{mg} / 18 \mathrm{~d}$ ) during the $18 \mathrm{~d}$ collection period in five rats given diets containing increasing amounts of $\mathrm{Na}$

\begin{tabular}{|c|c|c|c|c|c|c|c|c|}
\hline \multirow[b]{2}{*}{$\operatorname{Diet}^{\dagger} \ldots$} & \multirow[b]{2}{*}{ I } & \multirow[b]{2}{*}{2} & \multirow[b]{2}{*}{3} & \multirow[b]{2}{*}{4} & \multirow[b]{2}{*}{5} & \multirow[b]{2}{*}{ SEM } & \multicolumn{2}{|c|}{$\begin{array}{c}\text { Statistical significance of } \\
\text { diet effects (df 20) }\end{array}$} \\
\hline & & & & & & & LIN & QUAD \\
\hline \multicolumn{9}{|l|}{ Coefficient } \\
\hline LIN & -13 & -8 & -3 & +7 & +17 & & & \\
\hline QUAD & +127 & -20 & -109 & -113 & +115 & & & \\
\hline \multicolumn{9}{|l|}{$\mathrm{Mg}$} \\
\hline Intake & $73 \cdot 8$ & 73.8 & $73 \cdot 8$ & $73 \cdot 8$ & $73 \cdot 8$ & - & - & - \\
\hline Faeces & $15 \cdot 6$ & $14 \cdot 4$ & $17 \cdot 7$ & $17 \cdot 1$ & $17 \cdot 1$ & $1 \cdot 26$ & NS & NS \\
\hline Urine & $21 \cdot 9$ & $21 \cdot 3$ & 19.8 & $18 \cdot 0$ & $24 \cdot 3$ & $1 \cdot 17$ & NS & $*$ \\
\hline Retention & $+36 \cdot 3$ & $+38 \cdot 1$ & $+36 \cdot 3$ & +38.7 & $+32 \cdot 4$ & $2 \cdot 41$ & NS & NS \\
\hline \multicolumn{9}{|l|}{$\mathrm{Na}$} \\
\hline Intake & $288 \cdot 0$ & $369 \cdot 0$ & $450 \cdot 0$ & $612 \cdot 0$ & $774 \cdot 0$ & - & - & - \\
\hline Faeces & $48 \cdot 6$ & $64 \cdot 2$ & 77.7 & $85 \cdot 8$ & $106 \cdot 8$ & $10 \cdot 65$ & $* * *$ & NS \\
\hline Urine & $271 \cdot 2$ & $374 \cdot 1$ & $466 \cdot 5$ & $573 \cdot 0$ & $707 \cdot 9$ & $16 \cdot 11$ & $* * *$ & NS \\
\hline Retention & $-31 \cdot 8$ & $-69 \cdot 3$ & $-94 \cdot 2$ & -46.8 & $-40 \cdot 7$ & $25 \cdot 67$ & NS & $* *$ \\
\hline \multicolumn{9}{|l|}{$\mathrm{K}$} \\
\hline Intake & $612 \cdot 0$ & $612 \cdot 0$ & $612 \cdot 0$ & $612 \cdot 0$ & $612 \cdot 0$ & - & - & - \\
\hline Faeces & $71 \cdot 1$ & 67.5 & $80 \cdot 7$ & 97.5 & $86 \cdot 1$ & $11 \cdot 22$ & NS & NS \\
\hline Urine & 483.9 & $524 \cdot 4$ & $513 \cdot 6$ & $542 \cdot 4$ & 526.8 & $11 \cdot 61$ & NS & NS \\
\hline Retention & $+57 \cdot 0$ & $+20 \cdot 1$ & $+17 \cdot 7$ & -27.9 & $-0 \cdot 9$ & $20 \cdot 61$ & $* *$ & $*$ \\
\hline
\end{tabular}

LIN, linear effect of increasing Na intake; QUAD, quadratic effect of increasing Na intake; NS, not significant. ${ }^{*} P<0.05,{ }^{* *} P<0.01,{ }^{* * *} P<0.001$.

$\dagger$ Diets 1, 2, 3, 4 and 5 provided $16,20 \cdot 5,25,34$ and $43 \mathrm{mg} \mathrm{Na} / \mathrm{d}$ respectively (for details of composition see p. 400 and Table 1).

¥. C. Mathers, personal communication.

\section{RESULTS}

Expt 1

Table 2 shows that although there was not a significant response in the excretion of $\mathrm{Mg}$ in the faeces to the increased $\mathrm{Na}$ intake, the excretion of $\mathrm{Mg}$ in the urine showed a significant $(P<0.05)$ quadratic response. The urinary excretion of $\mathrm{Mg}$ fell as the $\mathrm{Na}$ intake was increased from $9 \mathrm{mg} / \mathrm{d}$ to $27 \mathrm{mg} / \mathrm{d}$, but rose again when $\mathrm{Na}$ intake was further increased to $36 \mathrm{mg} / \mathrm{d}$. 
Table 3. Expt 1. The effect of increasing sodium intake on the concentration of magnesium, $\mathrm{Na}$, potassium and aldosterone in plasma and in various tissues at the end of the 18 collection period in five rats

\begin{tabular}{|c|c|c|c|c|c|c|c|c|}
\hline \multirow[b]{2}{*}{$\operatorname{Diet} \uparrow \ldots$} & \multirow[b]{2}{*}{1} & \multirow[b]{2}{*}{2} & \multirow[b]{2}{*}{3} & \multirow[b]{2}{*}{4} & \multirow[b]{2}{*}{5} & \multirow[b]{2}{*}{ SEM } & \multicolumn{2}{|c|}{$\begin{array}{l}\text { Statistical significance of } \\
\text { diet effects (df 20) }\end{array}$} \\
\hline & & & & & & & LIN & QUAD \\
\hline \multicolumn{9}{|l|}{ Coefficient $\ddagger$} \\
\hline LIN & -13 & -8 & -3 & +7 & +17 & & & \\
\hline QUAD & +127 & -20 & -109 & -113 & +115 & & & \\
\hline \multicolumn{9}{|l|}{$\mathrm{Mg}$} \\
\hline Plasma (mmol/1) & $1 \cdot 17$ & $1 \cdot 23$ & 0.92 & 0.90 & $1 \cdot 06$ & $0 \cdot 10$ & NS & NS \\
\hline \multicolumn{9}{|l|}{ Tissue $(\mu \mathrm{g} / \mathrm{g})$} \\
\hline Heart & 783 & 638 & 664 & 603 & 673 & $35 \cdot 9$ & NS & * \\
\hline Liver & 459 & 494 & 437 & 583 & 551 & $48 \cdot 2$ & NS & NS \\
\hline Muscle & 847 & 885 & 839 & 582 & 779 & $38 \cdot 4$ & NS & $*$ \\
\hline Bone & 2154 & 2094 & 2140 & 2274 & 2008 & $83 \cdot 4$ & NS & NS \\
\hline \multicolumn{9}{|l|}{$\mathrm{Na}$} \\
\hline Plasma (mmol/l) & 151 & 155 & 147 & 144 & 148 & $4 \cdot 55$ & NS & NS \\
\hline \multicolumn{9}{|l|}{ Tissue $(\mathrm{mg} / \mathrm{g})$} \\
\hline Heart & $4 \cdot 5$ & $4 \cdot 0$ & $3 \cdot 8$ & 3.9 & $3 \cdot 8$ & $0 \cdot 16$ & $* *$ & NS \\
\hline Liver & $1 \cdot 6$ & $1 \cdot 5$ & 1.6 & $2 \cdot 0$ & $2 \cdot 0$ & $0 \cdot 16$ & $*$ & NS \\
\hline Muscle & $1 \cdot 7$ & $1 \cdot 6$ & $1 \cdot 8$ & $1 \cdot 8$ & $1 \cdot 5$ & $0 \cdot 15$ & NS & NS \\
\hline Bone & $4 \cdot 7$ & $4 \cdot 2$ & $4 \cdot 3$ & $4 \cdot 1$ & $4 \cdot 0$ & $0 \cdot 13$ & $* *$ & $\mathrm{NS}$ \\
\hline \multicolumn{9}{|l|}{$\mathrm{K}$} \\
\hline Plasma (mmol/l) & $7 \cdot 6$ & $6 \cdot 4$ & $5 \cdot 4$ & $5 \cdot 9$ & $5 \cdot 1$ & 0.50 & $* *$ & NS \\
\hline \multicolumn{9}{|l|}{ Tissue $(\mathrm{mg} / \mathrm{g})$} \\
\hline Heart & $9 \cdot 1$ & $8 \cdot 4$ & $7 \cdot 9$ & $7 \cdot 8$ & $7 \cdot 8$ & 0.40 & $*$ & NS \\
\hline Liver & $2 \cdot 7$ & $3 \cdot 8$ & $3 \cdot 5$ & $4 \cdot 7$ & $4 \cdot 1$ & 0.42 & NS & NS \\
\hline Muscle & $7 \cdot 1$ & $7 \cdot 5$ & $7 \cdot 7$ & $9 \cdot 4$ & $6 \cdot 8$ & 0.54 & NS & $*$ \\
\hline Bone & $3 \cdot 3$ & $3 \cdot 7$ & $3 \cdot 5$ & $4 \cdot 0$ & $3 \cdot 4$ & $0 \cdot 14$ & NS & NS \\
\hline $\begin{array}{l}\text { Plasma aldosterone } \\
(\mathrm{mmol} / \mathrm{l})\end{array}$ & 1.02 & 2.02 & $1 \cdot 29$ & $1 \cdot 17$ & 1.06 & $0 \cdot 261$ & NS & NS \\
\hline
\end{tabular}

LIN, linear effect of increasing Na intake; QUAD, quadratic effect of increasing Na intake; NS, not significant.

* $P<0.05, * * P<0.01$.

$\uparrow$ Diets 1, 2, 3, 4 and 5 provided $16,20 \cdot 5,25,34$ and $43 \mathrm{mg} \mathrm{Na} / \mathrm{d}$ respectively (for details of composition, see p. 400 and Table 1).

$\ddagger$ J. C. Mathers, personal communication.

The Na excretion and balance values responded as expected to the increase in $\mathrm{Na}$ intake. $\mathrm{Na}$ excretion in faeces and urine rose in a highly significant $(P<0.001)$ linear response. There were no significant effects of increased $\mathrm{Na}$ intake on the excretion of $\mathrm{K}$ in faeces or urine.

The results relating to the plasma values at the end of the collection period are shown in Table 3. There were no significant effects of dietary $\mathrm{Na}$ intake on plasma concentrations of $\mathrm{Mg}, \mathrm{Na}$ or aldosterone. There was a highly significant $(P<0 \cdot 01)$ linear decrease in the circulating concentrations of $\mathrm{K}$ as $\mathrm{Na}$ intake was increased.

The mean concentrations of $\mathrm{Mg}$ in various tissues at the end of the experiment are also shown in Table 3 . Increasing the $\mathrm{Na}$ intake produced a significant $(P<0.05)$ quadratic effect on the heart and muscle $\mathrm{Mg}$ concentration, with a gradual decrease from diet 1 to diet 4 , followed by a pronounced increase with the highest $\mathrm{Na}$ intake. There were no effects of diet on the $\mathrm{Mg}$ concentration in the liver or the femur.

There was a highly significant $(P<0.01)$ linear decrease in the Na content of the heart and femur as $\mathrm{Na}$ intake increased, and a significant $(P<0.05)$ linear increase in the $\mathrm{Na}$ 
Table 4. Expt 2. Mean output of magnesium, sodium and potassium in faeces and urine ( $\mathrm{mg} / 18 \mathrm{~d}$ ) during the $18 \mathrm{~d}$ collection period in five rats given diets containing adequate $(16 \mathrm{mg} / \mathrm{d})$ or high $(23.5 \mathrm{mg} / \mathrm{d})$ levels of $\mathrm{Na}$ and adequate $(88 \mathrm{mg} / \mathrm{d})$ or high $(142 \mathrm{mg} / \mathrm{d})$ levels of $K$

\begin{tabular}{|c|c|c|c|c|c|c|c|c|}
\hline \multirow{7}{*}{$\begin{array}{l}\text { Dietary } \mathrm{Na} \ldots \\
\text { Dietary } \mathrm{K} . . \\
\text { Diet } \dagger \ldots \\
\text { Coefficients } \\
\mathrm{Na} \\
\mathrm{K} \\
\mathrm{Na} \times \mathrm{K}\end{array}$} & 16 & $23 \cdot 5$ & 16 & $23 \cdot 5$ & \multirow{6}{*}{\multicolumn{4}{|c|}{$\begin{array}{l}\text { Statistical significance of } \\
\text { diet effects (df 16) }\end{array}$}} \\
\hline & 88 & 88 & 142 & 142 & & & & \\
\hline & 1 & 2 & 3 & 4 & & & & \\
\hline & \multirow{4}{*}{$\begin{array}{l}-1 \\
-1 \\
+1\end{array}$} & \multirow{4}{*}{$\begin{array}{l}-1 \\
+1 \\
-1\end{array}$} & \multirow{4}{*}{$\begin{array}{l}+1 \\
-1 \\
-1\end{array}$} & \multirow{4}{*}{$\begin{array}{l}+1 \\
+1 \\
+1\end{array}$} & & & & \\
\hline & & & & & & & & \\
\hline & & & & & & & & \\
\hline & & & & & SEM & $\mathrm{Na}$ & $\mathrm{K}$ & $\mathrm{Na} \times \mathrm{K}$ \\
\hline \multicolumn{9}{|l|}{$\mathrm{Mg}$} \\
\hline Intake & $131 \cdot 4$ & 131.4 & 131.4 & $131 \cdot 4$ & - & - & - & - \\
\hline Faeces & 29.4 & $28 \cdot 2$ & $30 \cdot 6$ & $31 \cdot 2$ & 1.92 & NS & NS & NS \\
\hline Urine & $23 \cdot 7$ & $20 \cdot 7$ & $28 \cdot 2$ & 18.6 & 2.49 & $*$ & NS & NS \\
\hline Retention & $+78 \cdot 3$ & $+82 \cdot 5$ & $+72 \cdot 6$ & $+81 \cdot 6$ & 4.98 & * & NS & NS \\
\hline \multicolumn{9}{|l|}{$\mathrm{Na}$} \\
\hline Intake & $288 \cdot 0$ & $423 \cdot 0$ & $288 \cdot 0$ & $423 \cdot 0$ & - & - & - & - \\
\hline Faeces & $17 \cdot 1$ & $18 \cdot 9$ & $20 \cdot 1$ & $37 \cdot 2$ & 4.41 & $*$ & $*$ & NS \\
\hline Urine & $421 \cdot 2$ & $572 \cdot 4$ & 456.9 & $531 \cdot 9$ & $14 \cdot 28$ & $* * *$ & NS & $*$ \\
\hline Retention & $-150 \cdot 3$ & $-168 \cdot 3$ & $-189 \cdot 0$ & $-146 \cdot 1$ & $15 \cdot 96$ & NS & NS & NS \\
\hline \multicolumn{9}{|l|}{$\mathbf{K}$} \\
\hline Intake & 1584 & 1584 & 2556 & 2556 & - & - & - & - \\
\hline Faeces & $39 \cdot 6$ & $52 \cdot 2$ & $37 \cdot 5$ & $79 \cdot 5$ & $7 \cdot 32$ & NS & NS & NS \\
\hline Urine & 1320 & 2418 & 1241 & 2310 & $52 \cdot 59$ & $*$ & NS & NS \\
\hline Retention & +224.4 & $-886 \cdot 2+$ & +1277.5 & $+166 \cdot 5$ & $5 I \cdot 62$ & $*$ & NS & NS \\
\hline
\end{tabular}

concentration in the liver. There were no significant effects of diet on the $\mathrm{Na}$ concentration of muscle.

There was a significant $(P<0.05)$ linear decrease in the $\mathrm{K}$ concentration in the heart as $\mathrm{Na}$ intake increased, but the muscle $\mathrm{K}$ concentration gradually increased between diets 1 and 4 then rapidly decreased at the highest level of $\mathrm{Na}$ intake. There were no significant effects of $\mathrm{Na}$ intake on the $\mathrm{K}$ concentration in the liver or femur.

\section{Expt 2}

As in Expt 1 there were no signifiant effects of $\mathrm{Na}$ or $\mathrm{K}$ intake, or both, on $\mathrm{Mg}$ faecal excretion, but significant $(P<0.05)$ increases in urinary excretion of $\mathrm{Mg}$ were detected when the diets without any additional $\mathrm{Na}$ (diets 1 and 3 ) were given; this increase was more pronounced when $\mathrm{K}$ intake was high (see Table 4). There were significant increases in the excretion of $\mathrm{Na}$ both in the faeces $(P<0.05)$ and urine $(P<0.001)$ when $\mathrm{Na}$ intake was increased. Increasing the $\mathrm{K}$ intake also significantly $(P<0.05)$ increased the excretion of $\mathrm{Na}$ in the faeces. Increasing the $\mathrm{Na}$ intake significantly $(P<0.05)$ increased the excretion of $\mathrm{K}$ in urine but not in faeces but there were no significant effects of dietary $\mathrm{K}$ on the excretion of $K$ in faeces or urine.

There were no significant effects of $\mathrm{Na}$ or $\mathrm{K}$ intake, or both, on the plasma concentrations of $\mathrm{Mg}$ or $\mathrm{K}$ but increasing the $\mathrm{Na}$ intake or the $\mathrm{K}$ intake, or both, significantly $(P<0.001)$ increased the plasma concentrations of $\mathrm{Na}$ (Table 5). Increasing both the $\mathrm{Na}$ and $\mathrm{K}$ intake significantly $(P<0.05)$ increased aldosterone levels.

Decreasing the $\mathrm{Na}$ intake significantly $(P<0.05)$ decreased the $\mathrm{Mg}$ concentration in the heart but there were no other significant effects of $\mathrm{Na}$ or $\mathrm{K}$ intake, or both, on the $\mathrm{Mg}$ 
Table 5. Expt 2. The effect of adequate $(16 \mathrm{mg} / \mathrm{d})$ or high $(23.5 \mathrm{mg} / \mathrm{d})$ sodium intake and adequate $(88 \mathrm{mg} / \mathrm{d})$ or high $(142 \mathrm{mg} / \mathrm{d})$ potassium intake on the concentration of magnesium, $\mathrm{Na}, \mathrm{K}$ and aldosterone in plasma and various tissues at the end of the $18 \mathrm{~d}$ collection period in five rats

\begin{tabular}{|c|c|c|c|c|c|c|c|c|}
\hline \multirow{7}{*}{$\begin{array}{l}\text { Dietary Na... } \\
\text { Dietary K... } \\
\text { Diet } \dagger \ldots \\
\text { Coefficients } \\
\quad \mathrm{Na} \\
\mathrm{K} \\
\mathrm{Na} \times \mathrm{K}\end{array}$} & \multirow{3}{*}{$\begin{array}{r}16 \\
88 \\
1\end{array}$} & \multirow{3}{*}{$\begin{array}{c}23.5 \\
88 \\
2\end{array}$} & & $23 \cdot 5$ & \multirow{5}{*}{ SEM } & & & \multirow{4}{*}{$\begin{array}{l}\text { cance of } \\
\text { If } 16 \text { ) }\end{array}$} \\
\hline & & & \multirow{2}{*}{$\begin{array}{r}142 \\
3\end{array}$} & \multirow{2}{*}{142} & & & & \\
\hline & & & & & & & & \\
\hline & \multirow{4}{*}{$\begin{array}{l}-1 \\
-1 \\
+I\end{array}$} & \multirow{4}{*}{$\begin{array}{l}-1 \\
+1 \\
-1\end{array}$} & \multirow{4}{*}{$\begin{array}{l}+1 \\
-1 \\
-1\end{array}$} & \multirow{4}{*}{$\begin{array}{l}+1 \\
+1 \\
+1\end{array}$} & \multirow{2}{*}{\multicolumn{4}{|c|}{$\begin{array}{l}\text { Statistical significance of } \\
\text { diet effects (df 16) }\end{array}$}} \\
\hline & & & & & & & & \\
\hline & & & & & & $\ldots$ & $\ldots$ & \\
\hline & & & & & & $\mathrm{Na}$ & $\mathrm{K}$ & $\mathrm{Na} \times \mathrm{K}$ \\
\hline $\mathrm{Mg}$ & & & & & & & & \\
\hline Plasma $(\mathrm{mmol} / \mathrm{l})$ & $1 \cdot 16$ & 0.84 & 0.77 & 0.70 & $0 \cdot 14$ & NS & NS & NS \\
\hline Tissue $(\mu \mathrm{g} / \mathrm{g})$ & & & & & & & & \\
\hline Heart & 528 & 568 & 477 & 602 & $35 \cdot 3$ & $*$ & NS & NS \\
\hline Liver & 515 & 491 & 493 & 471 & $30 \cdot 4$ & NS & NS & NS \\
\hline Muscle & 764 & 703 & 809 & 728 & $35 \cdot 7$ & NS & NS & NS \\
\hline Bone & 2574 & 2718 & 2583 & 2360 & $147 \cdot 2$ & NS & NS & NS \\
\hline $\mathrm{Na}$ & & & & & & & & \\
\hline Plasma (mmol/l) & 166 & 225 & 229 & 239 & $7 \cdot 10$ & $* * *$ & $* * *$ & $* *$ \\
\hline Tissue $(\mathrm{mg} / \mathrm{g})$ & & & & & & & & \\
\hline Heart & $3 \cdot 27$ & 380 & $3 \cdot 64$ & $4 \cdot 18$ & $0 \cdot 30$ & NS & NS & NS \\
\hline Liver & $1 \cdot 74$ & $1 \cdot 40$ & 1.49 & $1 \cdot 41$ & 0.15 & NS & NS & NS \\
\hline Muscle & $1 \cdot 72$ & 1.53 & $1 \cdot 78$ & $1 \cdot 44$ & $0 \cdot 10$ & $*$ & NS & NS \\
\hline Bone & 624 & $7 \cdot 09$ & $6 \cdot 91$ & $7 \cdot 10$ & $0-38$ & NS & NS & NS \\
\hline $\mathrm{K}$ & & & & & & & & \\
\hline Plasma (mmol/l) & $8 \cdot 4$ & $8 \cdot 7$ & $8 \cdot 6$ & $8 \cdot 6$ & $0 \cdot 38$ & NS & NS & NS \\
\hline Tissue $(\mathrm{mg} / \mathrm{g})$ & & & & & & & & \\
\hline Heart & 5.81 & $6 \cdot 34$ & $5 \cdot 04$ & 5.99 & $0 \cdot 36$ & NS & NS & NS \\
\hline Liver & 5.69 & $5 \cdot 34$ & $6 \cdot 11$ & $5 \cdot 86$ & 0.36 & NS & NS & NS \\
\hline Muscle & $9 \cdot 83$ & $9 \cdot 85$ & $10 \cdot 33$ & $9 \cdot 70$ & 0.47 & NS & NS & NS \\
\hline Bone & $3 \cdot 10$ & $3 \cdot 51$ & $2 \cdot 82$ & $3 \cdot 40$ & $0 \cdot 27$ & NS & NS & NS \\
\hline $\begin{array}{l}\text { Plasma aldosterone } \\
(\mathrm{mmol} / \mathrm{l})\end{array}$ & $2 \cdot 17$ & $1 \cdot 57$ & $2 \cdot 28$ & $2 \cdot 94$ & $0 \cdot 352$ & NS & $*$ & $*$ \\
\hline
\end{tabular}

NS, not significant.

$* P<0.05, * * P<0.01,{ }^{* * *} P<0.001$.

$\uparrow$ For details of composition, see p. 400 and Table 1.

concentrations of the remaining tissues analysed. Decreasing the $\mathrm{Na}$ intake significantly $(P<0.05)$ increased the $\mathrm{Na}$ concentration in the muscle but there were no other significant effects of $\mathrm{Na}$ or $\mathrm{K}$ intake, or both, on the $\mathrm{Na}$ concentration in the remaining tissues analysed. There were no significant differences in the $\mathrm{K}$ concentration in any of the tissues analysed.

\section{DISCUSSION}

As expected in Expt 1, increasing the $\mathrm{Na}$ intake significantly increased the linear excretion of $\mathrm{Na}$ both in faeces and urine. However, there were no significant effects of $\mathrm{Na}$ intake on plasma $\mathrm{Na}$, plasma $\mathrm{Na}$ being tightly controlled by a variety of hormones including aldosterone. The plasma aldosterone concentrations in Expt 1 showed no significant variation with $\mathrm{Na}$ intake. This was probably due to the $\mathrm{Na}$ intake being above requirements in all the diets ((US) National Research Council, 1978) and a low $\mathrm{Na}$ intake is required to stimulate aldosterone. Increasing the $\mathrm{Na}$ intake significantly increased the $\mathrm{Na}$ concentration of the heart, suggesting an increase in the intracellular concentration of $\mathrm{Na}$ in the heart muscle, and there was a significant decrease in the $\mathrm{Na}$ concentration in the femur. 
Increasing the $\mathrm{Na}$ intake in Expt 1 had no significant effect on the excretion of $\mathrm{K}$ in faeces or urine but did significantly lower plasma $\mathrm{K}$ concentrations linearly. Extracellular $\mathrm{K}$ in the plasma did not appear to be shifting intracellularly into the tissues as none of the tissues analysed showed any significant increase in $\mathbf{K}$ concentration.

The most noticeable feature of the findings relating to $\mathrm{Mg}$ was the gradual decrease in the excretion of $\mathrm{Mg}$ in the urine as $\mathrm{Na}$ intake was increased from diet 1 to diet 4 , followed by a marked increase with diet 5 . This was not related to the apparent absorption of $\mathrm{Mg}$ from the gut as there were no significant changes in the excretion of $\mathrm{Mg}$ in the faeces as $\mathrm{Na}$ intake increased.

The increased excretion of $\mathrm{Mg}$ in the urine at low and at high $\mathrm{Na}$ intakes may be due to the loss of intracellular $\mathrm{Mg}$ from the tissues. At times of low $\mathrm{Na}$ intake, the body tissues act as a reservoir for $\mathrm{Na}$, mobilization of which will release not only $\mathrm{Na}$ but $\mathrm{Mg}$ and $\mathrm{K}$ into the circulation (Larvor, 1976; Duarte, 1980; Schricker, 1985), which may account for the increased excretion of $\mathrm{Mg}$ at low $\mathrm{Na}$ intakes. The findings relating to the tissue $\mathrm{Mg}$ content are shown in Table 3 ; heart and muscle showed the same quadratic response in $\mathrm{Mg}$ content as did the urine, i.e. a decrease from diet 1 to diet 4 followed by an increase. This may have been due to storage of $\mathrm{Mg}$ in the tissues but does not account for their origin or the origin of the $\mathrm{Mg}$ excreted in the urine.

An explanation for the increased excretion of $\mathrm{Mg}$ in the urine at low $\mathrm{Na}$ intakes relates to the ionic exchange of $\mathrm{Mg}^{2+}$ for $\mathrm{K}^{+}$in the kidney tubules; evidence from previous work (Samley et al. 1960; Lemann et al. 1970) has suggested that at times of low Na intake, increased amounts of $\mathrm{Mg}$ are excreted in the urine as an ion-exchange for $\mathrm{K}$. The findings relating to the excretion of $\mathrm{K}$ in the urine (Table 2) would tend to support this hypothesis, i.e. when the intake of $\mathrm{Na}$ was at its lowest, diet 1 , the excretion of $\mathrm{K}$ in the urine was at its lowest and the excretion of $\mathrm{Mg}$ at its highest. No explanation can be offered for the increased excretion of $\mathrm{Mg}$ in the urine at high $\mathrm{Na}$ intakes. The findings relating to the excretion of $\mathrm{Mg}$ in the faeces have shown no significant responses to the variation in $\mathrm{Na}$ intake.

In Expt 2, the $\mathrm{Na}$ and $\mathrm{K}$ intakes were maintained at adequate or high intakes and it was hoped that increasing the $\mathrm{K}$ intake would stimulate the endogenous secretion of aldosterone. As can be seen from the results presented in Table 5, there was a significant effect of increasing $\mathrm{K}$ intake on plasma aldosterone concentrations.

Again increasing the $\mathrm{Na}$ intake significantly increased its loss in faeces and urine and surprisingly, bearing in mind the results produced in Expt 1, increasing the $\mathrm{Na}$ intake increased the plasma $\mathrm{Na}$ concentrations. These increases in plasma $\mathrm{Na}$ appear to be very difficult to explain considering the attendant natriuresis.

Increasing the $\mathrm{K}$ intake produced no natriuresis and had no effect on the faecal excretion of $\mathrm{Na}$, results which do not concur with those reported by Duarte (1980). The doubling of $\mathrm{K}$ intake produced no significant effect on any $\mathrm{K}$ variable but increasing the $\mathrm{Na}$ intake virtually doubled $\mathrm{K}$ excretion in the urine, probably by increasing the secretion of $\mathrm{K}$ by late distal tubules and cortical collecting ducts (Valtin, 1983). Duarte (1980) demonstrated that increasing the $\mathrm{K}$ intake of rats produced a kaliuresis and an accumulation of $\mathrm{K}$ in heart and bone, but the results presented in Tables 4 and 5 indicate that we were unable to demonstrate any significant effect of $\mathrm{K}$ intake on urinary excretion or tissue $\mathrm{K}$ concentration.

The $\mathrm{Mg}$ results presented in Expt 2 (Table 4) essentially confirm those of Expt 1. Again the $\mathrm{K}$ excretion findings support the explanation of ionic exchange at lower $\mathrm{Na}$ intakes. However, in relation to the content of $\mathrm{Mg}$ in the tissues, the results of Expt 2 do not concur with those of Expt 1. In Expt 2 the concentration of $\mathrm{Mg}$ in the heart increased with increasing $\mathrm{Na}$ intake whereas in Expt 1 the animals which had the lowest $\mathrm{Na}$ intake had 
heart tissue containing the highest $\mathrm{Mg}$ concentration. The most likely explanation for this difference is the much higher $\mathrm{K}$ intake of the animals in Expt 2.

In Expt 2 the plasma $\mathrm{Mg}$ levels were lower in the high-K groups (diets 3 and 4 ) compared with the adequate $\mathrm{K}$ groups (diets 1 and 2). Although this result was not statistically significant, other workers (Alexander \& Levinsky, 1968; Duarte, 1974) have also found that in rats fed on a high- $\mathrm{K}$ diet, there was a significant reduction in plasma $\mathrm{Mg}$ which could not be related to increased losses of $\mathrm{Mg}$ in the urine.

In summary, lowering the $\mathrm{Na}$ intake or increasing the $\mathrm{K}$ intake, or both, increases the excretion of $\mathrm{Mg}$ in the urine, but any link with aldosterone remains tenuous. Increasing the $\mathrm{K}$ intake had no significant effect on $\mathrm{K}$ excretion, whereas increasing the $\mathrm{Na}$ intake increased the excretion of $\mathrm{K}$ in urine. Dietary manipulation of $\mathrm{Na}, \mathrm{K}$ and $\mathrm{Mg}$ produced no conclusive effects on plasma or tissue $\mathrm{Na}, \mathrm{K}$ and $\mathrm{Mg}$ concentrations.

The authors wish to acknowledge the advice given by J. C. Mathers of the Department of Agricultural Biochemistry and Nutrition, University of Newcastle upon Tyne concerning statistics and the production of the manuscript. They also thank Professor Benraad of the University of Nijmegen, The Netherlands, for the generous donation of an antibody to aldosterone. J.A.C. was supported by a grant from the Meat and Livestock Commission.

\section{REFERENCES}

Alexander, E. A. \& Levinsky, N. G. (1968). An extrarenal mechanism of potassium adaption. Journal of Clinical Investigation $47,740-748$.

DeMan, A. J. M., Hofman, J. A., Hendriks, Th., Rosmalen, F. M. A., Ross, H. A. \& Benraad, Th. (1980). A direct radioimmunoassay for aldosterone: significance of endogenous cortisol. Netherlands Journal of Medicine 23, 7983.

Dixon, W. J. (1983). BMDP Statistical Software. Berkeley, California: University of California Press.

Duarte, C. G. (1974). Magnesium loading in potassium-adapted rats. American Journal of Physiology 227, $482-486$.

Duarte, C. G. (1980). Magnesium metabolism in potassium-adapted rats. In Magnesium in Health and Disease, pp. 93-103 [M. Cantin and M. S. Seelig, editors]. Laurel, Maryland: Spectrum Publishers.

Ebel, H. \& Günther, T. (1980). Magnesium metabolism: a review. Journal of Clinical Chemistry and Clinical Biochemistry 18, 257-270.

Forbes, R. M. (1966). Effect of magnesium, potassium and sodium nutriture on mineral composition of selected tissue of the albino rat. Journal of Nutrition 88, 400411.

Hanna, S. \& MacIntyre, I. (1960). The influence of aldosterone upon magnesium metabolism. Lancet ii, 348-350.

Kirkbright, G. F. \& Sargent, M. [editors] (1974). Practical techniques of atomic absorption and atomic fluorescence spectroscopy. In Atomic Absorption and Fluorescence Spectroscopy, pp. 441-505. London: Academic Press.

Larvor, P. (1976). ${ }^{28} \mathrm{Mg}$ kinetics in ewes fed normal or tetany prone grass. Cornell Veterinarian 66, 413-429.

Lemann, J., Piering, W. F. \& Lennon, E. J. (1970). Studies of the acute effects of aldosterone on the interrelationship between renal sodium, calcium and magnesium in normal man. Nephron 7, 117-130.

Morris, J. G. \& Gartner, R. J. W. (1975). The effect of potassium on the sodium requirement of growing steers with and without $\alpha$-tocopherol supplementation. British Journal of Nutrition 34, 1-14.

National Research Council (1978). Nutrient requirements of the laboratory rat. In Nutrient Requirements of Laboratory Animals, vol. 10, 3rd ed., pp. 7-37. Washington, D.C.: U.S. National Academy of Sciences.

Ryan, M. P. \& Whang, R. (1983). Interrelationships between potassium and magnesium. In Potassium: Its Biologic Significance, pp. 97-106. [R. Whang, editor]. Boca Raton, Florida: CRC Press.

Samley, A. H. E., Brown, J. L., Globus, D. L., Kessler, R. H. \& Thompson, D. D. (1960). Interrelations between renal transport system of magnesium and calcium. American Journal of Physiology 198, 595-602.

Schricker, B. (1985). Effect of dietary potassium sources on apparent absorption and retention of potassium, magnesium and sodium. Nutrition Reports International 31, 615-626.

Scott, D. \& Dobson, A. (1965). Aldosterone and the metabolism of magnesium and other minerals in sheep. Quarterly Journal of Experimental Physiology 50, 42-56.

Valtin, H. (1983). $\mathrm{Na}^{+}$and $\mathrm{H}_{2} \mathrm{O}$ transport. Sodium balance. In Renal Function, pp. 10I-126. Boston: Little, Brown and Co. 